\title{
Leucine aminopeptidase in the pancreatic juice during ethionine pancreatitis
}

\author{
KURT MÜLLER-WIELAND ${ }^{1}$ \\ From Manchester Royal Infirmary
}

EDITORIAL SYNOPSIS In the early stages of ethionine pancreatitis leucine aminopeptidase output was increased while the excretion of amylase, trypsin, and lipase was diminished.

Müller-Wieland and Becker (1962) have reported an increase of leucine aminopeptidase in the duodenal juice of man after stimulating the exocrine pancreas. The present experiments were designed to investigate the pattern of leucine aminopeptidase output in normal rats and in animals poisoned with ethionine.

\section{METHODS}

Pancreatic juice was withdrawn from 41 male albino rats ranging in weight from 200 to $300 \mathrm{~g}$. in an acute experiment. The exocrine pancreas was stimulated by secretin and pancreozymin (Boots). The technical details have already been described in full (Müller-Wieland, 1964). The activity of the enzymes amylase (Norby, quoted by Lagerlöf, 1942) trypsin (Gowenlock, 1953), lipase (Marchis-Mouren, Sarda, and Desnuelle, 1959), and leucine aminopeptidase (Goldbarg and Rutenburg, 1958) was estimated in fractions of pancreatic juice. Pancreatitis was caused by ethionine.

Male rats only were used, because of the excessive fatty degeneration of the liver in female rats in the early stage of ethionine toxicity (Farber, Koch-Weser, and Popper, 1951; Becker 1957).

\section{RESULTS}

CONTROLS In six animals the standard errors of the mean for volume, and output of amylase, trypsin, lipase, and leucine aminopeptidase were, in the secretin period, $8 \cdot 13,7 \cdot 57,10 \cdot 7,6 \cdot 68$, and $9 \cdot 25 \%$, and in the pancreozymin period $12 \cdot 6,12 \cdot 7,10 \cdot 7,11 \cdot 2$, and $5.82 \%$. The relationship of enzyme output during the post-secretin and post-pancreozymin phases was $5 \cdot 56: 1,2 \cdot 95: 1,2 \cdot 43: 1$, and $2 \cdot 40: 1$ (Table I).

INCREASING DOSES OF ETHIONINE (EXPERIMENTAL GROUPS $1-5$ ) In rats given from 0.33 to $1.00 \mathrm{mg}$./g. body weight of ethionine the volumes of the pancre-

'Address: I. Medizinische Klinik, Universitat Hamburg, 2 Hamburg 20, Martinistrabe 52 . atic juice remained within the normal range with a variation of one standard deviation from the mean in most animals (groups 1-3). With doses of 1.33 and $1.66 \mathrm{mg}$./g. body weight (groups 4 and 5) the volumes decreased. The excretion of leucine aminopeptidase increases in the early stages of the ethionine pancreatitis. This was particularly noticeable in the postpancreozymin phase. In group 3 the output was $260 \%$ of the normal while the excretion of amylase, trypsin, and lipase was impaired. The leucine aminopeptidase output remains increased in spite of higher doses of ethionine (groups 4 and 5) which caused considerable damage to acinar cell function (Table I and Figure 1).

EXOCRINE FUNCTION OF THE PANCREAS ONE, TWO, THREE, AND FIVE DAYS AFTER ETHIONINE POISONING (EXPERIMENTAL GROUPS 3, 6-8) The rats were given $1.00 \mathrm{mg}$./g. body weight of ethionine as three single doses (each $0.33 \mathrm{mg}$./g. body weight). The exocrine pancreatic function was tested after $24,48,72$, and 120 hours.

Following the injections of ethionine the output of amylase, trypsin, and lipase showed a fall which became maximal on the second day. The excretion of leucine aminopeptidase was diminished during the post-secretin phase and increased in the postpancreozymin period. Thereafter the output of amylase, trypsin, and lipase was gradually restored to normal by the fifth day. However, at this time the rise in leucine aminopeptidase output reached $264 \%$ of normal in the post-secretin phase (Table I and Figure 2).

\section{DISCUSSION}

In the pancreatic secretion of normal rats the pattern of leucine aminopeptidase excretion was comparable with that of trypsin and lipase. In the earlier stages of ethionine pancreatitis leucine aminopeptidase out- 
TABLE I

VOLUME AND OUTPUT OF AMYLASE, TRYPSIN, LIPASE, AND LEUCINE AMINOPEPTIDASE AFTER SECRETIN AND PANCREOZYMIN AND MEANS AND SIGNIFICANCE OF DIFFERENCE BETWEEN MEANS OF NORMAL AND ABNORMAL GROUPS OF RATS WITH ETHIONINE PANCREATITIS

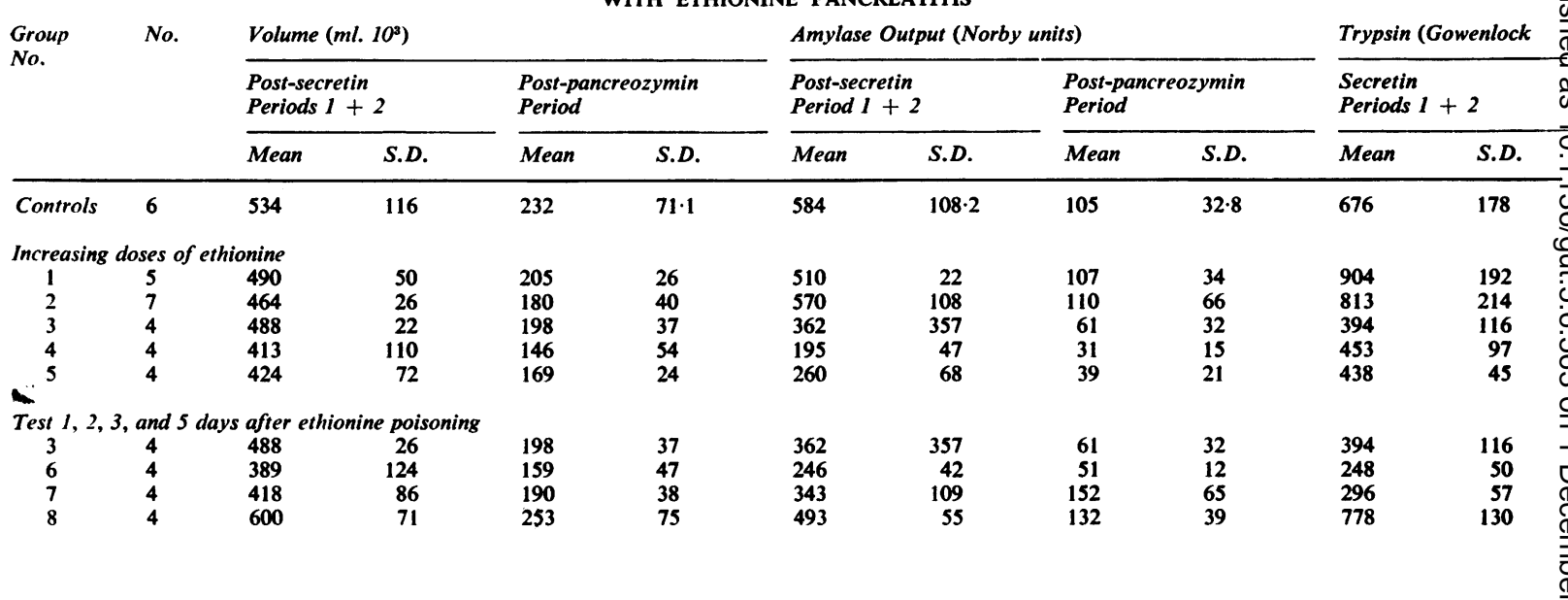

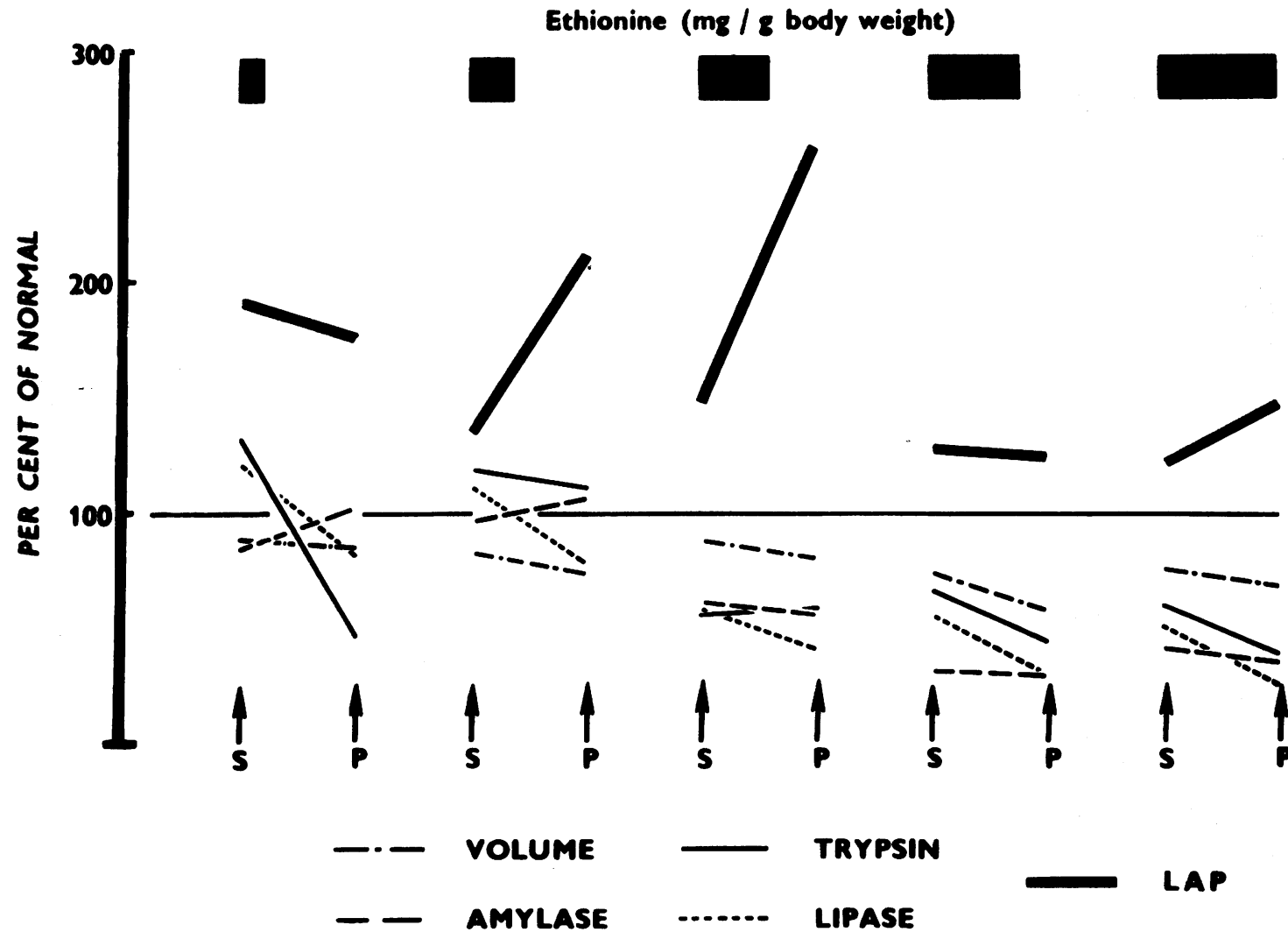

FIG. 1. Means of volume and output of amylase, trysin, lipase, and leucine aminopeptidase in the post-secretin and post-pancreozymin period of groups of rats with pancreatitis induced by increasing doses of ethionine correlated with the means of normals. 
TABLE I-continued

VOLUME AND OUTPUT OF AMYLASE, TRYPSIN, LIPASE, AND LEUCINE AMINOPEPTIDASE AFTER SECRETIN AND PANCREOZYMIN AND MEANS AND SIGNIFICANCE OF DIFFERENCE BETWEEN MEANS OF NORMAL AND ABNORMAL GROUPS OF RATS WITH ETHIONINE PANCREATITIS

\begin{tabular}{|c|c|c|c|c|c|c|c|c|c|c|c|}
\hline \multicolumn{2}{|c|}{ Units) } & \multicolumn{4}{|c|}{ Lipase (Desnuelle units) } & \multicolumn{6}{|c|}{ Leucine Aminopeptidase (units) } \\
\hline \multicolumn{2}{|c|}{$\begin{array}{l}\text { Pancreozymin } \\
\text { Period }\end{array}$} & \multicolumn{2}{|c|}{$\begin{array}{l}\text { Secretin } \\
\text { Periods } 1+2\end{array}$} & \multicolumn{2}{|c|}{$\begin{array}{l}\text { Pancreozymin } \\
\text { Period }\end{array}$} & \multicolumn{2}{|c|}{ Secretin } & \multicolumn{2}{|l|}{$\begin{array}{l}\text { Period } \\
2\end{array}$} & \multicolumn{2}{|c|}{$\begin{array}{l}\text { Pancreozymin } \\
\text { Period }\end{array}$} \\
\hline Mean & S.D. & Mean & S.D. & Mean & S.D. & Mean & S.D. & Mean & S.D. & Mean & S.D. \\
\hline 232 & 61 & 235 & $38 \cdot 7$ & 100 & $16 \cdot 4$ & $34 \cdot 1$ & $7 \cdot 55$ & $25 \cdot 9$ & $5 \cdot 58$ & $24 \cdot 1$ & 3.43 \\
\hline $\begin{array}{r}284 \\
257 \\
138 \\
108 \\
95\end{array}$ & $\begin{array}{l}62 \\
58 \\
55 \\
16 \\
11\end{array}$ & $\begin{array}{l}295 \\
276 \\
147 \\
135 \\
131\end{array}$ & $\begin{array}{l}41 \\
49 \\
55 \\
50 \\
28\end{array}$ & $\begin{array}{l}84 \\
79 \\
44 \\
30 \\
30\end{array}$ & \begin{tabular}{r|}
$27 \cdot 2$ \\
$16 \cdot 8$ \\
$17 \cdot 7$ \\
$9 \cdot 2$ \\
$1 \cdot 0$
\end{tabular} & $\begin{array}{l}68 \cdot 2 \\
36 \cdot 3 \\
35 \cdot 0 \\
51 \cdot 7 \\
51 \cdot 4\end{array}$ & $\begin{array}{l}9 \cdot 74+++ \\
4 \cdot 03 \\
3 \cdot 36 \\
9 \cdot 34+ \\
15 \cdot 28\end{array}$ & $\begin{array}{l}45 \cdot 2 \\
44 \cdot 9 \\
53 \cdot 3 \\
24 \cdot 6 \\
22 \cdot 6\end{array}$ & $\begin{array}{l}5 \cdot 67+++ \\
5 \cdot 20 t+ \\
3 \cdot 65 t+ \\
3 \cdot 21 \\
5 \cdot 82\end{array}$ & $\begin{array}{l}42 \cdot 2 \\
51 \cdot 3 \\
62 \cdot 8 \\
30 \cdot 1 \\
35 \cdot 6\end{array}$ & $\begin{array}{l}4 \cdot 77++t \\
4 \cdot 68+t+ \\
2 \cdot 31+t+ \\
19 \cdot 7 \\
16 \cdot 2\end{array}$ \\
\hline $\begin{array}{l}138 \\
105 \\
123 \\
254\end{array}$ & $\begin{array}{l}55 \\
33 \\
39 \\
62\end{array}$ & $\begin{array}{l}147 \\
114 \\
219 \\
249\end{array}$ & $\begin{array}{l}55 \\
32 \\
35 \\
57\end{array}$ & $\begin{array}{l}44 \\
35 \\
69 \\
83\end{array}$ & $\begin{array}{r}17 \cdot 7 \\
9 \cdot 1 \\
18 \cdot 2 \\
17 \cdot 6\end{array}$ & $\begin{array}{l}35 \cdot 0 \\
30 \cdot 1 \\
48 \cdot 8 \\
125\end{array}$ & $\begin{array}{c}\mathbf{3} \cdot 36 \\
\mathbf{3} \cdot \mathbf{8 2} \\
\mathbf{9 \cdot 3 9} \\
\mathbf{2 2 \cdot 8}+++\end{array}$ & $\begin{array}{l}53 \cdot 3 \\
14 \cdot 4 \\
28 \cdot 1 \\
35 \cdot 2\end{array}$ & $\begin{array}{l}3 \cdot 65+t \\
3 \cdot 92+t \\
1.68 \\
35 \cdot 3+t\end{array}$ & $\begin{array}{l}62 \cdot 8 \\
31 \cdot 2 \\
34 \cdot 5 \\
31 \cdot 3\end{array}$ & $\begin{array}{l}2 \cdot 31+++ \\
4 \cdot 01+ \\
3 \cdot 51+t \\
5 \cdot 39\end{array}$ \\
\hline \multicolumn{12}{|c|}{ 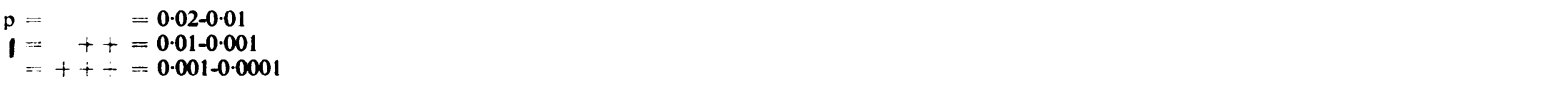 } \\
\hline
\end{tabular}

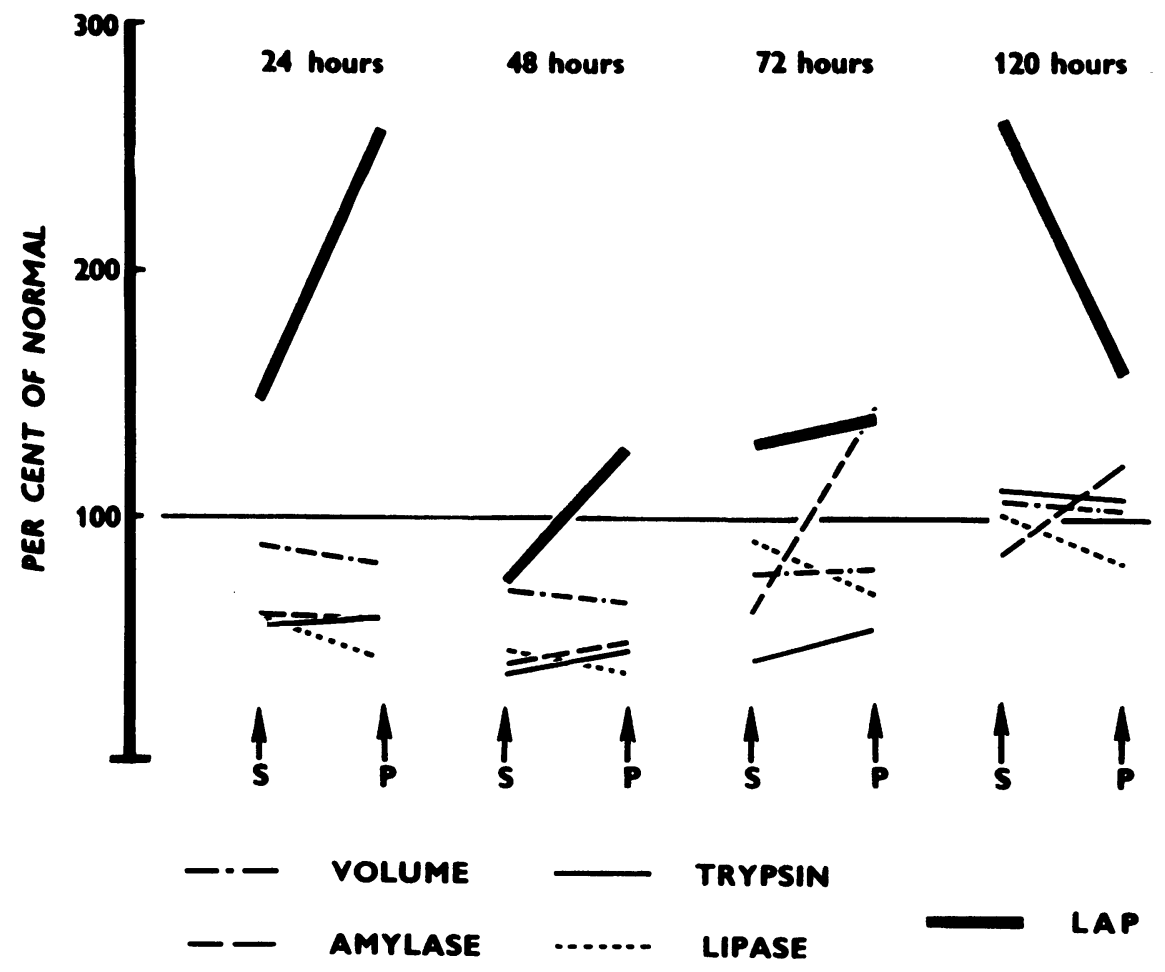

FIG. 2. Means of volume and output of amylase, trypsin, lipase, and leucine aminopeptidase in the post-secretin and post-pancreozymin period of groups of rats with ethionine pancreatitis in the recovery period correlated with the means of normals. 
put increased while the poisoning impaired the excretion of amylase, trypsin, and lipase. Ethionine thus affects the excretion of these enzymes in a different manner.

In the groups receiving small doses of ethionine the increasing output of leucine aminopeptidase during the post-pancreozymin period showed that it is not likely to be synthesized and excreted with the other three enzymes.

\section{CONCLUSION}

The pancreatic juice of the rat contained leucine aminopeptidase. The pattern of output of amylase, trypsin, lipase, and leucine aminopeptidase was similar in normals. Ethionine affected the excretion of leucine aminopeptidase and the other enzymes in a different manner. At the beginning of ethionine pancreatitis the secretion of leucine aminopeptidase increased, particularly in the post-pancreozymin phase. Leucine aminopeptidase is not likely to be synthesized and excreted with the other three enzymes.
Dr. Henry T. Howat, Manchester Royal Infirmary, made this study possible. I acknowledge his help and the help of Professor A. C. P. Campbell, of the Department of Pathology, and of Professor Walter Schlapp, of the Department of Physiology, University of Manchester. I am grateful to Dr. G. Williams, Dr. A. H. Gowenlock, and Dr. C. Crompton. Finally, I am indebted to the British Council, who arranged for me to study in Great Britain.

\section{REFERENCES}

Becker, V. (1957). Sekretionsstudien am Pankreas. Thieme, Stuttgart. Farber, E., Koch-Weser, D., and Popper, H. (1951). The influence of sex and of testosterone upon fatty liver due to ethionine. Endocrinology, 48, 205-212.

Goldbarg, J. A., and Rutenburg, A. M. (1958). The colorimetric determination of leucine aminopeptidase in urine and serum of normal subjects and patients with cancer and other diseases. Cancer (Philad.), 11, 283-291.

Gowenlock, A. H., (1953). The estimation of tryptic activity in duodenal contents. Biochem. J., 53, 274-277.

Lagerlöf, H. (1942). Pancreatic function and pancreatic disease studied by means of secretin. Acta med. scand. suppl., 128.

Marchis-Mouren, G., Sarda, L., and Desnuelle, P. (1959). Purification of hog pancreatic lipase. Arch. Biochem. 83, 309-319.

Müller-Wieland, K. (1964) Alterations of the enzyme output in ethionine pancreatitis Gut, 5, 567-572.

- - , and Becker, K. (1962). Die Leucinaminopeptidase-Aktivität im Duodenalsaft vor und nach Anregung der Pankreassekretion. Dtsch. Arch. klin. Med., 208, 193-205. 